\title{
Detecting metaphor - what case forms may reveal about a conceptualization
}

\author{
OLGA SOKOŁOWSKA
}

Received 12.10.2018,

received in revised form 12.01.2019,

accepted 17.01.2019.

\begin{abstract}
The figurativeness of language expressions is not always obvious. While in rhetoric such unobtrusiveness may be a welcome quality, in linguistic studies, which have proved the important epistemological function of metaphor, it is vital that a reliable method for detecting metaphoricity in language be developed. The MIP proposed by the Pragglejaz group of researchers into metaphor, whose main concern is determining whether the sense represented by a given unit in a specific context contrasts or not with its basic, primary, typically "physical" meaning, does not seem to be always reliable since the contrast between a current and a basic meaning is not always evident and may be disputable in the case of words whose meaning is co-determined by context, as, e.g., the sense of the noun collectors in the phrase collectors of stories referring to the Grimm brothers. This method is also likely allow for the so-called grammatical metaphors, identified by Panther and Thornburg (2009) going unnoticed, since in their case the words involved represent their basic, physical senses. An example of the latter is the peculiar inflection of brand names marked for the masculine gender in Polish. Specifically, this is the issue of obligatory applying the declensional pattern characteristic of masculine animate nouns to masculine brand names referring to commercial products, such as cars,
\end{abstract}


watches, computers, etc. The point is that the accusative case form of such words functioning as objects of verbs like buy, see, have is equal to the genitive, as is normal of animate nouns, rather than to the nominative, which is typical of animate ones - a group, to which brand names, after all, belong. This peculiar behaviour of a specific category of nouns may be interpreted as a symptom of construing their referents in a way in terms of living creatures, which seems to be confirmed by the fact that many owners develop emotional attitudes to objects of personal use. It is the metaphorical construal that seems to determine the grammatical form of certain nouns referring to them.

\title{
Keywords
}

metaphor identification, grammatical metaphor, declension

\section{Jak rozpoznać metaforę - obrazowanie figuratywne a przypadek gramatyczny}

\begin{abstract}
Abstrakt
Rozpoznawalność językowych wyrażeń metaforycznych jest kwestia nieoczywista; figuratywność niektórych zwrotów jest latwa do zauważenia, natomiast stwierdzenie jej w przypadku innych, szczególnie wysoce skonwencjonalizowanych, wymaga sporej spostrzegawczości i wprawy. Z punktu widzenia retoryki, stopień rozpoznawalności metaforyczności przez odbiorcę oracji powinien być, dla nadania jej cech wiarygodności, jak najniższy, jednak językoznawcy, wobec bardzo ważnego w podejściu kognitywnym założenia, że analiza języka otwiera drogę do zrozumienia sposobu ludzkiego myślenia, powinni dysponować metodą pozwalająca na niezawodne wykrycie metaforycznego użycia danej jednostki leksykalnej. Taka metoda, opracowana przez grupę badaczy określająca się mianem Pragglejaz polega na ustaleniu, czy znaczenie danego wyrazu w konkretnym kontekście kontrastuje w jakiś sposób $z$ jego znaczeniem podstawowym, pierwotnym, najczęściej odnoszącym się do rzeczywistości materialnej. Metoda ta nie wydaje się być, jednak, niezawodna, bowiem nie zawsze jest jasne, czy znaczenie danego słowa $\mathrm{w}$ danym użyciu kontrastuje $\mathrm{z}$ jego
\end{abstract}


znaczeniem podstawowym, szczególnie, gdy jest ono doprecyzowane przez kontekst, jak np. znaczenie rzeczownika collectors $\mathrm{w}$ zwrocie collectors of stories określającym braci Grimm. Innym przykładem figuratywności niewykrywalnej dla MIP sa tzw. metafory gramatyczne (zob. Panther i Thornburg (2009), bowiem w ich przypadku użyte wyrazy moga reprezentować swoje podstawowe, „fizyczne” znaczenia. Jako taką właśnie metaforę można uznać specyficzny sposób odmiany przez przypadki pewnego typu rzeczowników rodzaju męskiego w języku polskim. Chodzi tu o stosowanie deklinacji właściwej dla rzeczowników żywotnych rodzaju męskiego do nazw firmowych produktów przemysłowych, takich, jak samochody, zegarki, komputery, etc. - dotyczy to ich formy biernika $\mathrm{w}$ roli dopełnienia czasowników przechodnich, np. kupić, zobaczyć, mieć. W przypadku rzeczowników nieżywotnych rodzaju męskiego jest ona prawie zawsze równa mianownikowi, natomiast nazwy firmowe (np. ford, volkswagen, rolex, samsung), nieodmiennie przyjmuja $\mathrm{w}$ tej pozycji formę równa dopełniaczowi, tak samo jak rzeczowniki żywotne. Może to być sygnałem obrazowania produktów przez nie oznaczanych jako istot żywych, co zdaje się potwierdzać fakt, że właściciele często mają do przedmiotów osobistego użytku stosunek emocjonalny. Taki metaforyczny sposób myślenia o przedmiotach określanych nazwami handlowymi wydaje się przesądzać o odmianie takich nazw w sposób właściwy dla rzeczowników żywotnych.

\section{Słowa kluczowe}

rozpoznanie metafory, metafora gramatyczna, deklinacja

\section{Introduction}

The issue of a method to detect metaphor in language has not been directly addressed by Lakoff and Johnson in their seminal work of 1980 . Actually, the authors put the reader immediately, on the very first page, in medias res in the process of unfolding their own, novel account of the phenomenon in question and its relevance to not only language, but, especially, to human cognition, comprehension and reasoning. Presenting the account of metaphor as a fun- 
damental cognitive strategy, they seem to take it for granted that the linguistic signals of the figurative mode of thinking are self-evident, even though the figurativeness of many of the considered examples could easily escape the notice of even a language-conscious user. Unfortunately, the authors do not provide any clues that could be referred to in recognizing metaphor, even though, as they admit, most examples discussed in their book are conventional, and some of them have even become dead. Indeed, it seems that many metaphorical expressions provided in the discussion would not strike most speakers as figurative in nature (e.g., Inflation is lowering our standard of living; You are wasting my time; My income rose last year; The theory needs more support).

\section{Detecting metaphor}

Definitely, some metaphorical mappings are so deeply ingrained in human thinking that the figurative nature of linguistic expressions instantiating them, typically highly conventionalized, is not likely to be noted by casual speakers. What is more, also specialists concerned with providing la strictly formal account of language and proposing to deal only with its "serious" uses, such as generative grammarians, did not manage to avoid resorting to metaphor explicating their theory (cf. such terms as embedding, deep/shallow structure, derivation, transformation, movement [of syntactic elements], etc.) Nevertheless, especially inconspicuous seem to be metaphorical extensions of the meaning of prepositions. In fact, they have become so highly conventionalized that it is impossible to avoid them in linguistic descriptions of conceptualized scenes. A classic example is the irrevocable use of spatial prepositions to refer to temporal relations, based on the general TIME IS A PHYSICAL OBJECT mapping, as, e.g., in I'll be finished in five minutes, They arrived on time; or in Polish Przyjde za pięć minut, literally 'I'll be there behind five minutes'; Wyjechali na tydzien,, literally 'They left onto a week'. The English examples reflect the conceptualization of a period 
of time in terms of a container, and of a point in time - in terms of a spatial location. The Polish sentences, in turn, appear to instantiate conceptualizing a period of time as a large object that may block progress, so it has to be got behind, or as a surface temporarily supporting the referents of the subject pronoun. Indeed, in all probability, pointing to the figurative nature of any of the aforementioned utterances would cause surprise in their users. This brings to mind Monsieur Jourdain, Molière's Bourgeois Gentleman, exclaiming in astonishment "These forty years now, I've been speaking in prose without knowing it!" By the same token, people speak in metaphor without knowing it, which makes the task of bringing its inconspicuous instances to light quite challenging. Nevertheless, it seems that the conceptual metaphor theory put forward by Lakoff and Johnson has become so powerful and influential in part thanks to illustrating it with scores of highly conventionalized, and hence hardly noticeable examples.

In references to metaphor made by linguists prior to the advent of the cognitive account of the phenomenon it seems that the examples provided were chosen intuitively, and they tended to be of obvious figurative nature, e.g. Grice (1975) presented the statement You are the cream in my coffee as a case of flouting of the Maxim of Quality, while Lyons (1968) or Palmer (1976), referring to metaphor, were concerned with the evidently figurative senses of words like eye, mouth, foot leaving the less conspicuous instances undiscussed. The latter were brought to the attention of linguistics only by Lakoff and Johnson without, as has already been pointed out, providing clues about their recognition. 


\subsection{The Metaphor Identification Procedure (MIP)}

Aristotle, the author of the first insightful account of figurative language in the Western world, considered unobtrusiveness to be characteristic of good and effective use of metaphor, as indicated in The Rhetoric,

[1404a]... A word in its prevailing and native meaning and metaphor are alone useful in the lexis of prose. A sign of this is that these are the only kinds of words everybody uses; for all people carry on their conversations with metaphors and words in their native and prevailing meanings. Thus, it is clear that if one composes well, there will be an unfamiliar quality and it escapes notice and will be clear $[\ldots]$

(http://people.wku.edu/jan.garrett/401s07/arismeta.html, translated by George A. Kennedy)

As can be concluded from the quoted excerpt, Aristotle was of the opinion that a "well-composed" metaphor will "escape notice", as a result of which a speech in which it is included will sound "native", hence more likely to take the intended persuasive effect. From the point of view of an orator, then, figurative language should appear as much as possible to be plain and undecorated to avoid raising suspicion on the part of the audience.

However, when metaphor was recognized to be first of all a matter of thought and began to be considered a valuable source of information concerning human cognition and reasoning, looking for its signals in language has become an occupation of many a researcher trying to accurately describe the relations holding between language and mind. Thus, the attitude to metaphor of such a researcher appears to be opposite to that of an orator; $\mathrm{s} / \mathrm{he}$ is avidly interested in bringing it to view rather than in concealing it. Being able to recognize even inconspicuous figurativeness, practically fused with literal meaning is also important in education since the theory of conceptual metaphor has become an integral and important part of academic courses in linguistics, so students 
should be able to recognize metaphor used in language on an everyday basis. It seems, therefore, that a reliable method to distinguish metaphor from non-metaphor in utterances is needed. In answer to this need, to avoid relying only on intuitions to detect the figurative nature of language units, which may sometimes prove fallible, a group of researchers calling themselves Pragglejaz have presented a method of identifying the metaphoricity of specific expressions used in linguistic communication. It is called the Metaphor Identification Procedure (MIP) and it involves the following steps:

1. recognizing the general meaning (topic) of the text/discourse in which a given expression (lexical unit) occurs (i.e., what the text/discourse concerns),

2. distinguishing all the units participating in the given text/discourse,

3. (a) recognizing the contextual meaning of a unit, i.e., how it relates to the situation described and how it contributes to the general meaning of the text/discourse, with the immediate cotext of the unit taken into account,

(b) considering whether there exists a more "basic" contemporary meaning of the unit considered. "Basic" meanings tend to be more physical, concrete, immediately related to sensory perception, bodily actions, precise and historically older,

(c) deciding whether the currently recognized meaning of a given unit contrasts with the more basic meaning, but can still be understood in relation to it.

4. If so, the given unit can be considered to have been used metaphorically. (adapted from http://www.academia.edu/235704 /MIP_A_method_for_identifying_metaphorically_used_words_in_di scourse)

The original Pragglejaz example to which the method has been applied is recognized to involve the following metaphorical expressions, marked by italics: "For years, Sonia Gandhi has struggled to convince Indians that she is fit to wear the mantle of the political dynasty into which she married, let alone to become premier". The singled out units do, indeed, in this 
context represent senses contrasting with the basic ones, so their figurativeness does not seem to raise any doubts.

\subsection{The MIP - some problems}

The method at the first sight seems simple and error-proof, yet it is likely to be outsmarted by language; an attempt to apply it to another, randomly selected sample of text has raised questions as regards its infallibilty. The text concerns the relevance of oral tradition to culture and runs as follows: "Traditions of storytelling are still strong in many parts of the world, but industrialization and urbanization are the enemies of oral narratives. [...] It is thanks to collectors following the example of the brothers Jacob and Wilhelm Grimm in Germany that many stories survived." As before, the italicized words seem to pass the MIP test without difficulty; the senses in which they are used do contrast with basic ones and are still understandable in the provided context. However, the metaphoric nature of the use of the underscored lexeme collectors in the quoted example seems to be debatable. As specified by Webster's New World Dictionary of the American Language, in one of its basic, physical senses the unit refers to a person gathering material objects, like stamps, books, etc., as a hobby (the other senses, related to a person whose work is collecting taxes, overdue bills, etc., or to an element of a technological device, are definitely not involved.) What causes the uncertainty is the fact that stories are not material objects to be collected on a par with stamps or books, but, on the other hand, when they are written down and gathered in a volume, which is what the Grimm brothers probably did collecting them, they assume a physical, tangible form and can be treated like other, typical collectibles. Therefore, it is not clear whether or not the currently recognized meaning of collectors valid in the provided context contrasts with the more basic meaning of the word simply because in this case the distinction between the basic, i.e., literal and the non-basic, i.e., metaphorical senses cannot be unequivocally drawn. An 
example like this may suggest that metaphoricity may be recognized as a measurable quality that characterizes the uses of specific language units in specific contexts to a higher or lower degree. Thus, it might be proposed that the use of the lexeme collectors in the quoted excerpt should be qualified as only slightly metaphorical.

As another instance of barely recognizable metaphoricity, rather undetectable for MIP, it is possible to consider the use of the noun car as subject of the verb stopped in Croft and Cruse's (2004: 210) example The car stopped in front of a building. Most researchers would probably consider it an instance of the OBJECT USED FOR USER metonymy, representing the FORM (A)-CONCEPT (A) FOR FORM (B)-CONCEPT (B) type, recognized by Kövecses and Radden (1998). Croft and Cruse, however, point to its indeterminacy as a concrete figure of speech, because the quoted combination of words may as well be indicative of the metaphorical mapping A CAR IS A LIVING CREATURE, i.e., of the animalization of a vehicle, even though the participation of a controller is necessarily involved. It should be observed, nevertheless, that the meaning represented by the verb stop considered independently, i.e., 'to block up', 'to cause to cease motion', cf. Webster's New World Dictionary of the American Language, is extremely schematic and does not include any presuppositions concerning the nature of the causing element. Notwithstanding, the prototypical one would be a human consciously performing a controlled action, as in the model of causation presented by Lakoff (1987: 54-55). It is, thus, very difficult to decide whether using the verb stop in a predicate complementing a subject referring to a less prototypical "causer", incapable of direct manipulation is metaphorical or not, and a car, as a movable object, is closer to the prototype than, e.g., fence, as in It was only a fence that stopped the skidding car. Still closer, though unspecific as to the controllability would be horse in The horse stopped by the barn.

It appears, therefore, that what decides about the degree of metaphoricity impact of certain uses of specific language units 
(lexemes) is the higher or lower prototypicality of situations in which their referents are involved; stop is non-metaphorical in The man stopped in front of a building but in situations in which less prototypical causation is recognized, the degree of metaphoricity (animalization, personification) may rise. By the same token, in the case of the previously discussed example of collectors, the metaphoricity is undetectable when the noun is complemented by a phrase referring to prototypical collectibles but its degree may be felt to rise when less prototypical ones, such as stories, jokes, smiles or souls (which Lucifer might be interested in) are at issue.

Another type of figurative construals reflected in language but undetectable by means of the MIP method seems to be the phenomenon that Panther and Thornburg (2009:17-22) describe as grammatical metaphor. This term covers instances of metaphorical processes exerting impact on grammar, i.e., the use and distribution of grammatical categories being determined by the mapping of a certain source notion onto a certain target notion. Thus, a grammatical metaphor does not depend on a specific non-standard use of lexical categories, in the case of which it would be traceable by the MIP, but it is rendered by a specific application of grammatical patterns. Such metaphor definitely outsmarts the method in question as the lexemes involved may well be used in their basic, standard senses. An example illustrating the issue provided by $\mathrm{P}$ and Th are, among others, the PAST IS PRESENT metaphor involved in the use of the Conversational Historical Present Tense in narration, whereupon a metaphorically used verb referring to a past event may express its standard meaning but assumes the present tense form (e.g., In June 1812 Napoleon's army invades Russia and retreats by December of the same year). Another example of grammatical metaphor recognized by $\mathrm{P}$ and $\mathrm{Th}$ in German is construing certain phenomena deprived of biological sex (a city, art) as females, which is motivated by the feminine grammatical gender of respective German nouns. This construal is indicated by the use of feminine versions of nouns functioning 
as complements of such nouns. Its reflection can be observed in other languages that possess the category of grammatical gender, such as Latin or Polish. An illustrative example is the adage Historia (fem.) magistra (fem.) vitae est and its Polish version Historia (fem.) jest nauczycielka (fem.) życia - 'History is life's teacher'.

A similar instance of grammatical metaphor in the case of which animalization of an inanimate entity is marked by a syntactic category (case form) rather than by a non-standard use of a lexeme can be found in Polish. It concerns inflecting by case of certain brand names occurring in the object position in a sentence.

\section{Grammatical metaphor signalled by case forms of certain nouns in Polish}

Lakoff and Johnson (1980: 38) provide the example of the sentence He bought a Ford as an illustrative instantiation of metonymy of the PRODUCER FOR PRODUCT type. They observe no metaphoric overtones therein carried. However, its exact translation into Polish, i.e., Kupit forda may raise questions concerning the actual mode of conceptualizing the situation described by the sentence - due to the grammatical case form of the object noun constituted by a brand name. As Polish is a highly synthetic language employing numerous inflectional patterns applicable to practically any grammatical category of words (only prepositions and adverbs do not submit to them), and because the forms that words assume when participating in larger units, such as phrases and sentences, are not always imposed with regard to only grammatical constraints (governance rules) and irrespectively of their meaning, they may constitute a source of valuable information concerning the construals of described scenes by language users.

Thus, there are disproportions between the declensional patterns to which count nouns (and brand names belong to this nominal subcategory) marked for one of the three 
grammatical genders recognized in Polish are submitted, with the evident special position of the masculine. The feminine and neuter nouns assume the same form (declensional suffix) in the accusative case representing the semantic role of the patient or the percept when they follow the Polish equivalents of such transitive verbs as buy, eat, have, see, read, i.e., when they perform the syntactic role of direct object, no matter whether they are animate or inanimate, e.g., Zauważyt 'He saw' dziewczyne 'a girl-acc. '; ksiażke 'a book-acc.' - feminine, or dziecko 'a child-acc.', krzesło 'a chair-acc.' - neuter. In the case of neuter nouns the accusative is always equal to the nominative whereas the feminine accusative is not conflated with any other case form.

In contrast to this, the inflection of masculine nouns, such as those occupying the object position in the examples provided below, is determined by their meaning; generally they assume different forms depending whether they are animate (then the accusative form is equal to the genitive) or inanimate (then, in the vast majority of cases the accusative form is equal to the nominative), e.g.,

(1) Wyprowadzit psa 'He walked the dog' (accusative = genitive)

(2) Zjadt pieczonego kurczaka 'He ate a roast chicken' (accusative = genitive)

(3) Kupił samochód 'He bought a car' (accusative = nominative)

(4) Zjadł obfity posilek 'He ate a big meal' (accusative = nominative)

It should be noted that the animateness of a roast chicken is at least dubious, yet the syntactic behaviour of the noun kurczak 'chicken' seems to be determined by the prototypical, canonical condition of its referent. This assumption is corroborated by the fact that also in the uses in which an animate noun refers to an obviously inanimate object, the form of such a noun in the direct object position is the same as in a prototypical application, cf. Cynowego koguta (accusative $=$ 
genitive) odnaleziono $w$ gruzach wewnatrz katedry "The tin cock was found in the rubble inside the cathedral'.

It can be mentioned, as a side note, that, despite the fact that inanimate masculine count nouns functioning as objects of transitive verbs normally assume the accusative form equal to the nominative - as in (3) and (4), some of them can take two alternative forms in this position, equal to the nominative or to the genitive, e.g., Pokrajat pomidor (acc. $=$ nom.) $/$ pomidora (acc. = gen.) 'He cut up a tomato'; Kupit arbuz (acc. = nom.) / arbuza (acc. = gen.) 'He bought a watermelon'; Zjadt cukierek (acc. $=$ nom.) / cukierka (acc. = gen.) 'He ate a sweet'. The choice of the case form in such instances is sometimes a matter of style, i.e., using the form equal to the genitive (pomidora, arbuza, cukierka) is considered rather informal, colloquial (cf. Bańko 2002, http://sjp.pwn.pl/slowniki /zje\%C5\%9B\%C4\%87\%20pomidor.html.), but sometimes choosing a specific case form of an object noun, especially if it refers to a potentially divisible entity, may communicate a differrence in conceptualizing its referent. The use of the accusative equal to the nominative is indicative of a holistic construal, e.g., Zjedlismy chleb (masc. acc = nom.) 'We ate the bread', while using the accusative equal to the genitive points to the fragmentary conceptualization of the respective entity, e.g., Zjedliśmy chleba (masc. acc = gen.) 'We ate some bread'. The possibility to choose a specific case form to express a holistic or a fragmentary construal of a referent also applies to nouns marked for the feminine or neuter grammatical gender, e.g., Zjedz zupe (fem. acc.) 'Eat the soup'; Przynies ciasto (neut. acc. = nom.) 'Bring the cake' vs. Zjedz zupy (fem. acc = gen.) 'Eat some soup'; Przynieś ciasta (neut. acc. = gen.) 'Bring some cake'.

Generally, however, the animate-inanimate distinction, which appears to be not at all clear-cut, is by far the most consequential in respect to inflecting by case the Polish masculine nouns occurring in the direct object position. Thus, when it comes to inanimate masculine nouns, their accusative form in the object position following transitive verbs pre- 
supposing the semantic roles of patient / percept is equal not to the genitive, as is the case with animate ones, but to the nominative, as in the following examples: Kupit samochód / zegarek / komputer 'He bought a car / a watch / a computer'. The sentences Kupit *samochodu / *zegarka / *komputera (with the accusative equal to the genitive, which would be normal for animate nouns) are definitely ill-formed. Yet, the situation changes when the very same objects are referred to not by means of their generic names (common nouns) but by means of the commercial brands which they represent, e.g. ford, fiat, opel, mercedes, boeing, rolex, samsung (in Polish brand names are not capitalized). If the name is of masculine gender, it declines in the same manner as a masculine animate noun, which means that in the object position it assumes the form equal to the genitive rather than the nominative, as the common nouns representing the categories to which such objects belong do, cf. Kupił samochód / zegarek / komputer 'He bought a car / a watch / a computer' (accusative $=$ nominative) vs. Kupił forda / fiata / volkswagena / rolexa / samsunga 'He bought a Ford / a Fiat / a Volkswagen / a Rolex / a Samsung' (accusative = genitive). Using the accusative form of brand names equal to the nominative, as in Kupit *ford / *fiat / *rolex / *volkswagen / *samsung would not be acceptable. What is more, it should be observed that the "animate" declension applies to all masculine brand names, not only eponymous ones, in whose case assuming such a form could in a way be motivated; out of the provided examples only ford is an eponym. It seems that the declension of masculine brand names according to the masculine animate pattern can be described as an instance of grammatical metaphor: A BRANDED OBJECT IS A LIVING CREATURE. Consequently, as predicted by Panther and Thornburg (2009: 16), the structure of the figurative language unit is shaped by the source domain, i.e., masculine brand names inflect like masculine animate nouns. In other words, metaphorical animalization of the referents of brand names results in applying the "animate" pattern in their declension. 


\section{Conceptions represented by brand names}

Brand names, though often eponymous in origin, are not proper names, which may be confirmed, among others, by their Polish orthography. However, they seem to be much closer to them than common nouns because they are adopted or devised to single out specific products on the market, therefore, their function is in a way similar to that of proper names. Still, apart from the referential function, typical of all nouns, they maintain some degree of predicability, i.e., they provide categorial information about their referents (cf. Anderson 1997), of which proper names are deprived or at least very short. In their case this is purely pragmatic, circumstantial meaning; for example, it is common knowledge that a Ford or a Volkswagen are cars, and many people are aware that a Rolex is a watch. Yet, brand names represent entire categories of objects rather than individual entities, which is why it is not possible to identify them as proper names per se.

Prototypically, proper names are given to people and special animals (predominantly pets), sometimes also to places or objects. Giving a proper or a quasi-proper name, such as, e.g., Carrie or Volks to such a material object as a car may be indicative of developing a special attitude towards it. It is, perhaps, not too farfetched to say that a so-named vehicle becomes, in a way, its owner's friend or pet, which is a symptom of the application of an animalistic metaphor. In English, a genderless language, the feminine pronoun she is sometimes used to refer to a ship or a car, which may also signal a special, emotional attitude of a speaker towards the referent.

Therefore, as it seems, the facts about the declension of masculine brand names in Polish may be invoked to confirm the hypothesis of the metaphorical construal (animalization) of certain inanimate objects. It may be, in other words, suggested that, if masculine brand names are declined according to the same pattern as masculine animate nouns, the objects 
represented by them are in a way conceptualized in terms of living creatures.

However, it would be hasty to draw a simple conclusion like the one formulated above because it can only apply to the singular form of respective nouns. The brand names' plural form would not provide any hint whatsoever of a possible metaphorical mapping involved. Simply, the accusative of a brand name in the plural form is equal to the nominative, as in the case of other Polish plural masculine animate or inanimate nouns, e.g. Maja dwa fordy / psy / domy 'They have two Fords / dogs / houses'. It is only personal masculine plural nouns that assume the forms equal to the genitive when in object position, e.g. Maja dwóch synów / doradców 'They have two sons / advisors'.

Therefore, the syntactic (inflectional) clue about the metaphoric nature of a specific construal of individual branded objects is very subtle and inconspicuous, especially that there are also some common masculine inanimate nouns declined in the "animate" way (typically foodstuffs). On the other hand, individual vehicles (ships, cars), just like other objects dear to their owners, are quite likely to be metaphorically animalized; the owners of machines for personal use (especially computers) often talk about them as if they were living and thinking creatures, e.g., My car is on its last legs; My computer refused to open that file; My computer went crazy. This may lead to the conclusion that some metaphors are full-fledged and clearly involve the mapping of two conception, while in the case of some other ones the mapping is less evident.

\section{Conclusions}

Despite the fact that the Metaphor Identification Procedure proposed by Pragglejaz is a helpful and in many cases effective instrument to be used in detecting metaphorical uses of language units, there are cases in which it does not provide a clear answer to the question whether a given use of a lexeme is figurative or not. It seems, therefore, that metaphors 
constitute a natural category comprising prototypical but also less representative examples. A signal of construals that may be of metaphoric nature could be constituted by, among others, certain uses of case forms in Polish constituting an instance of what Panther and Thornburg have termed grammatical metaphor, in whose case the lexemes involved represent standard, non-figurative meanings but assume grammatical forms that depart from the standard. All in all, the described facts seem to support the general assumption valid in cognitive linguistics (cf. Langacker 1987) that grammatical patterns (such as, among others, case forms) are meaningful symbolic units.

\section{References}

Anderson, John M. (1997). A Notional Theory of Syntactic Categories. Cambridge: Cambridge University Press.

Aristotle. The Rhetoric. Trans. George A. Kennedy. Excerpts available at <http://people.wku.edu/jan.garrett/401s07/arismeta.html>. Accessed 12.12.2016.

Bańko, Mirosław (2002). "Zjeść pomidor". Available at <http:// sjp.pwn.pl/slowniki/zje\%C5\%9B\%C4\%87\%20pomidor.html>; $<$ http://sjp.pwn.pl/poradnia>. Accessed 18.08.2016.

Croft, William, D. Alan Cruse (2004). Cognitive Linguistics. Cambridge: Cambridge University Press.

Grice, H. Paul (1975). "Logic and conversation". In: Peter Cole, Jerry L. Morgan (eds.). Syntax and Semantics. Vol. 3: Speech Acts. New York: Academic Press, 4-58.

Kövesces Zoltan, Günter Radden (1998). "Metonymy: Developing a cognitive linguistic view". Cognitive Linguistics 9/1: 37-77.

Lakoff, George (1987). Women, Fire and Dangerous Things. Chicago: The University of Chicago Press.

Lakoff, George, Mark Johnson (1980). Metaphors We Live By. Chicago - London: The University of Chicago Press.

Langacker, Ronald W. (1988). "An overview of cognitive grammar". In: Brygida Rudzka-Ostyn (ed.). Topics in Cognitive Linguistics. Amsterdam - Philadelphia: John Benjamins, 3-43. 
Lyons, John (1968). Introduction to Theoretical Linguistics. Cambridge: Cambridge University Press.

Palmer, Frederick, R. (1976). Semantics: A New Outline. Cambridge: Cambridge University Press.

Panther, Klaus-Uwe, Linda L. Thornburg, Antonio Barcelona (2009). Metonymy and Metaphor in Grammar. Amsterdam - Philadelphia: John Benjamins Publishing Company.

Pragglejaz Group (2007). "MIP: A method for identifying metaphorically used words in discourse". Metaphor and symbol 22/1: 1-39. Available at <http://www.academia.edu/235704/ MIP_A_method_for_identifying_metaphorically_used_words_in_dis course>. Accessed 25.07.2016.

Olga Sokołowska

ORCID iD: 0000-0002-4722-113X

Instytut Anglistyki i Amerykanistyki

Uniwersytet Gdański

ul. Wita Stwosza 51

80-308 Gdańsk

Poland

olga.sokolowska@ug.edu.pl 